\title{
34. PRELIMINARY PALYNOLOGY OF SAMPLES FROM SITE 254, NINETYEAST RIDGE
}

\author{
Elizabeth M. Kemp, Bureau of Mineral Resources, Canberra, Australia
}

\section{INTRODUCTION}

Preliminary palynological study has been carried out on five samples from Site 254 (lat $30^{\circ} 58.15^{\prime}$ S, long $\left.87^{\circ} 53.72^{\prime} \mathrm{E}\right)$, drilled in 1253 meters of water on the southern end of the Ninetyeast Ridge.

Recovery from the samples was as follows:

Sample 28-1, 126-128 cm-Spores and pollen present but rare, preservation fair.

Sample 29-1, 124-128 cm-Spores and pollen abundant and well preserved; plant tissue and fungal debris common.

Sample 30-1, 53-57 cm-Spores and pollen sparse; plant tissue and fungi common.

Sample 32-1, 103-105 cm-Some doubtfully identified plant tissue, no spores or pollen.

Sample 33-1, 80-84 cm-As for Sample 32-1, 103-105 $\mathrm{cm}$.

Preservation of plant microfossil material from Cores 28-30 was generally good; that from Core 29 was outstanding. In this sample, pollen has been observed still united in tetrads and larger clusters. Fungal debris, consisting of vegetative hyphae, fruiting bodies, and spores, is abundant in all samples, as are plant cuticle fragments. The excellence of preservation, the relatively large size of some spores and pollen, and the general diversity of plant fossils suggests that the remains have not been transported far from their growth site. No organic-walled marine microfossils, i.e., dinoflagellates or acritarchs, were observed in any sample.

\section{COMPOSITION OF ASSEMBLAGES}

The following comments are based on a relatively detailed analysis of Core 29. The assemblages from other core samples differ only slightly, chiefly in the relative abundance of different groups. Approximately 25 angiosperm species have been recognized, with 10 fern spore species, 1 gymnosperm, and an indeterminate number of fungal spore types. In terms of actual grain numbers, slightly over half of the grains observed were of angiosperm origin.

Few of these can be identified with previously described Tertiary species. The most abundant species is a large, thick-walled tricolporate form, here referred to as Rhoipites sp. 2, the affinity of which is unknown. Also common are grains comparable with Tricolpites reticulatus, which was originally described from probable early Miocene horizons on Kerguelen (Cookson, 1947), and whose affinity lies probably with the Gunneraceae. Another angiosperm type of considerable interest is a verrucate, syncolpate pollen of unknown affinity, referable to the form-genus Meyeripollis. This taxon has previously only been recorded from Eocene to Miocene strata in Assam (Baksi, 1962; Baksi and Venkatachala,
1970), although Muller (personal communication) has observed it in the early Tertiary of Borneo.

Pollen of the families Gramineae and Compositae, which are important elements of the extant vegetation of the sub-Antarctic islands, is present but very rare in the Ninetyeast Ridge samples. Pollen produced probably by members of the palm family is slightly more abundant.

Of particular paleogeographic interest is a group of pollen types which are common in Australasian early Tertiary sequences. Included here are myrtaceous forms similar to Myrtaceidites mesonesus Cookson and Pike, proteaceous pollens comparable to Proteacidites symphonemoides Cookson, and the form species Cupanieidites orthoteichus Cookson and Pike. These are consistent elements in Australian and New Zealand Tertiary microfloras, and probably derived from a distinctive southern flora, which was distributed in the early Tertiary through Australia, Antarctica, New Zealand, and southern South America. Their presence in the Ninetyeast Ridge samples raises important problems in the long-distance dispersal of their parent plant groups.

Among fern spores, the most common types are smooth-walled trilete spores representing at least two species of Cyathidites, indicating the probable presence of a significant tree-fern element in the vegetation. Other types include monolete spores referable to Laevigatosporites. Peromonolites, and Verrucatosporites (the latter probably representing the polypodiaceous ferns), and trilete types referable to Polypodiaceoisporites (bearing some resemblance to living Pteris species).

Pollen produced by Podocarpaceae occurs in small, though significant amounts. This coniferous family is essentially southern in its distribution, but extends northward through the Indonesian archipelago. Fungal remains are abundant and include juvenile stages of microthyriaceous groups, which were probably epiphyllous in habit, as well as a diversity of spore types and masses of hyphae.

\section{AGE OF THE ASSEMBLAGE}

Dating by palynological means is difficult because of the high proportion of new species. None of the forms which Germeraad et al. (1968) used to delineate a system of pan-tropical Tertiary palynological zones has been identified. Moreover, the Australasian elements present are long-ranging types. Broad inferences only can therefore be drawn concerning the age of the deposit. The presence of rare high-spined Compositae is suggestive of a post-Oligocene age (Germeraad et al., 1968). The genus Meyeripollis is presently known to be confined to late Eocene to early Miocene strata in Assam; the presence of this form genus may fix a younger age limit for the assemblage somewhere in the 
early Miocene. The Ninetyeast Ridge form is specifically distinct, however, so that its time range may not be identical. The very low frequency of Compositae and Gramineae may reinforce, in a somewhat negative way, a minimum age limit of approximately early Miocene.

\section{PALEOECOLOGY AND PALEOGEOGRAPHY}

The pollen assemblage is a well-mixed one, suggesting that there is no over-representation of local species and that deposition occurred at a site removed from the parent plant communities. The microflora possibly represents a lagoonal environment of deposition, an area which may have been subject to periodic marine incursions. A lagoonal situation with fringing mangrove vegetation might be expected in such a position, but no pollen of known mangrove species was positively identified. The excellence of preservation suggests that deposition occurred under anaerobic conditions, such as those which prevail in waterlogged areas where decomposition is arrested at shallow depths.

The relatively high diversity of both angiosperm and pteridophyte spores, and of epiphytic fungal remains suggests a warm, possibly at least subtropical, and certainly an extremely humid environment. The abundance of fungi of the family Microthyriaceae, which presently has a world-wide tropical distribution, may support such a climatic interpretation, although there are some instances of occurrences of this group in higher latitudes. There is possibly a high degree of endemism at generic level, which is characteristic of an island biota, although some of this "endemism" may merely reflect the present inadequacies of Tertiary palynology. When emergent, Site 254 lay probably to the south of $30^{\circ} \mathrm{S}$ latitude; the only Indian Ocean islands currently in comparable latitudes are Amsterdam and St. Paul at $37^{\circ} \mathrm{S}$. These islands have floras which are considerably less diverse than that which is suggested by the pollen spectrum at Site 254. Some 17 flowering plant species are known from these modern islands (Good, 1964), compared to at least 25 from Site 254. The decrease in diversity is probably related to a complex of factors, among which Neogene chilling of the southern Indian Ocean is probably significant.

\section{COMPARISON WITH OTHER TERTIARY MICROFLORAS}

\section{Australia, New Zealand, Antarctica}

The most notable difference between Site 254 microflora and southern assemblages is the lack of Nothofagus at Site 254; pollen of the southern beech family is usually dominant in Tertiary assemblages from Australia, New Zealand, and southern South America. An abundance and diversity of proteaceous and myrtaceous pollens and of podocarpaceous types are also distinctive features of Austral microfloras; these groups are represented in very low frequencies in the Ninetyeast Ridge microflora.

\section{Kerguelen}

The microflora from Kerguelen lignites (Cookson, 1947 ) is probably of comparable age to that from Site
254, but may represent a much cooler environment, though probably one of similar humidity. The Kerguelen assemblages are dominated by coniferous pollen, with Podocarpaceae and Araucariaceae being abundantly represented. Only five flowering plant species are known. There is, in common with Site 254 , a lack of Nothofagus, an abundance of fern spores, and the presence of microthyriaceous fungi.

\section{Southern India, Assam, Andaman Islands}

Tertiary microfloras are known from southern India (Ramanujam, 1966), Assam (Baksi, 1962), and the Andaman Islands (Banerjee, 1966). Although these studies encompassed Miocene strata, the assemblages have little in common with that from Site 254. The only forms common to both regions are Meyeripollis, already mentioned, and palm-like pollens. These last are present in much greater abundance and diversity in the Asian microfloras.

\section{TAXONOMIC NOTES}

In the descriptive notes which follow, all dimensions given, unless otherwise stated, are based on measurement of at least 15 specimens. Abundances are based on a count of 250 specimens from Sample 29-1, 124-128 cm.

\section{SYSTEMATICS \\ Angiospermae \\ Dicotyledoneae \\ Genus TRICOLPITES Cookson ex Couper, emend Potonié. Tricolpites sp. cf. T. reticulatus Cookson 1947 (Plate 1, Figures 1-5)}

Dimensions: Equatorial diameter $18(21) 29 \mu \mathrm{m}$, polar diameter, 18(19)21 $\mu \mathrm{m}$.

Distribution and affinities: Forms included here show a narrow range of morphologic variation. They are possibly conspecific with $T$. reticulatus from the probable early Miocene of Kerguelen (Cookson, 1947), but reticulum is coarser. Cookson and Pike (1954) recorded $T$. (al Gunnerites) reticulatus from New Guinea Pliocene; Hekel (1972) identified a similar form from early Tertiary sediments in Queensland. The dispersed grains resemble those of the extant genus Gunnera (Family Gunneraceae; cf. G. bracteata in Heusser [1971], G. perpensa in Straka et al.[1967]). Common, around 3\% of sample counted.

Tricolpites sp.

(Plate 1, Figures 6-8)

Dimensions: Equatorial diameter, 25(28) $31 \mu \mathrm{m}$; polar diameter, 17(19)21 $\mu \mathrm{m}$.

Remarks: Does not compare closely with any described from the Australian-New Zealand region. Prolate, tricolpate pollen with a reticulate exine occurs in a number of extant families (Labiatae, Cruciferae, Bignoniaceae). The species shows some resemblance to pollen of the extant genus Tecoma (Bignoniaceae). Common, approximately $8 \%$ of assemblage.

\section{Tricolpites sp. cf. T. asperamarginatus Mclntyre 1968}

(Plate 1, Figures 14, 15)

Dimensions: Equatorial diameter, $18(23) 26 \mu \mathrm{m}$ (seen in polar view only).

Remarks: Mclntyre (1968) described T. asperamarginatus from the Paleocene of New Zealand. Hekel (1972) recorded it from Queensland sediments ranging in age from ?early Tertiary to middle Miocene. Common, approximately $3 \%$ in Site 254 samples. 
Genus STRIATRICOLPORITES (van der Hammen) Leidelmeyer 1966

Striatricolporites sp.

(Plate 1, Figures 9-13)

Dimensions: Equatorial diameter, 10(12)15 $\mu \mathrm{m}$; polar diameter, 13(17) $22 \mu \mathrm{m}$.

Remarks: Characterized by an equatorial pore, which is difficult to discern. S. minor, from the Eocene of Borneo (Muller, 1968) and Paleocene-Miocene of Queensland (Hekel, 1972), is larger with a longer polar axis and thinner exine. Affinities lie possibly with the Anacardiaceae, but could also be with Leguminosae, Sapindaceae, Burseraceae, and Cucurbitaceae. Rare, $1 \%$.

\section{Genus RHOIPITES Wodehouse 1933}

Rhoipites sp. 1

(Plate 1, Figures 16-18)

Dimensions: Equatorial diameter, $9(11) 14 \mu \mathrm{m}$; polar diameter, 15(17) $19 \mu \mathrm{m}$

Remarks: Differs from Miocene Kerguelen species Tricolporites prolata Cookson in having a reticulate exine, and from the Australian Paleocene to Miocene $T$. microreticulatus Harris in its smaller size. Affinities could lie with a number of dicotyledonous families, including Flacourtiaceae, Euphorbiaceae, and Lobeliaceae. Common, around $7 \%$ of assemblage.

Rhoipites sp. 2

(Plate 1, Figures 21-30)

Dimensions: Equatorial diameter, 20(26)31 $\mu \mathrm{m}$; polar diameter $35(42) 49 \mu \mathrm{m}$.

Remarks: No similar forms have been described from Australian and New Zealand Tertiary sediments. Tricolporites angurium, described by Partridge (1971) from the Eocene of the Gippsland Basin, has a thinner exine and finer reticulum. Affinities uncertain; comparable pollen occurs, however, in some Rutaceae. Common, about $10 \%$ of assemblage.

\section{Genus MALVACIPOLLIS Harris 1965 \\ ef. Malvacipollis sp. \\ (Plate 1, Figures 23-26)}

Dimensions: Overall diameter $14-20 \mu \mathrm{m}$ (7 specimens).

Remarks: This form is only tentatively referred to Malvacipollis which is zoniporate. Aperture development is obscure in the Ninetyeast Ridge species; pores can rarely be discerned at the surface, but three or four apertures have been detected in optical section in some grains. Apertural rims have not been identified. Rare to common, 3$4 \%$ of assemblage.

Genus ECHITRICOLPORITES van der Hammen, ex Germeraad et al., 1968

cf. Echitricolporites sp.

(Plate 1, Figures 19, 20)

Dimensions: Equatorial diameter, $21-23 \mu \mathrm{m}$ ( 3 specimens).

Remarks: A rare form, only tentatively assigned to this genus, as the presence of equatorial pores has not been definitely established.

Genus CUPANIEIDITES Cookson and Pike, ex Krutzsch 1959

Cupanieidites orthoteichus

Cookson and Pike ex Potonié 1960

(Plate 2, Figure 1)

Dimensions: Equatorial diameter 15(19)22 $\mu \mathrm{m}$.

Remarks: Conforms closely to the original description of Cookson and Pike (1954). Occurs in Australia in Paleocene to Pliocene strata. Affinities probubly lie with the Cupanieae of the family Sapindaceae. Rare, $1 \%$.

Genus MYRTACEIDITES Cookson and Pike, ex Potonié 1960

\section{Myrtaceidites sp. cf. M. mesonesus Cookson and Pike}

(Plate 2, Figures 2-4)

Dimensions: Equatorial diameter 14(16)22 $\mu \mathrm{m}$.

Remarks: Specimens from Site 254 are more strongly sculptured than $M$. mesonesus, which occurs in Australian Eocene to Pliocene
(Cookson and Pike, 1954; Partridge, 1971; Martin, 1972). Cookson and Pike noted a similarity to species of Eucalyptus, but recognition of affinity below family level in Myrtaceae is hazardous. Rare, about $1 \%$ of assemblage.

\section{Genus MEYERIPOLLIS Baksi and Venkatachala 1970 Meyeripollis sp. \\ (Plate 2, Figures 7-12)}

Dimensions: Equatorial diameter 16(22) $23 \mu \mathrm{m}$.

Remarks: Forms grouped here include a wide range of morphologic variation, which appears continuous; end members with development of large verrucae at grain angles clearly fall within Meyeripollis, which is presently monotypic. This record is the first for the genus outside Assam, the type locality, where it is known from late Eocene to probably early Miocene strata (Baksi, 1962; Baksi and Venkatachala, 1970). The type species, $M$. naharkotensis, also occurs in sediments of comparable age in Borneo (J. Muller, personal communication). Affinities unknown. Common, up to $8 \%$ of assemblage.

\section{Genus PROTEACIDITES Cookson ex Couper 1953 \\ Proteacidites sp. cf. P. symphonemoides Cookson 1950 \\ (Plate 2, Figures 5, 6)}

Dimensions: Equatorial diameter $21-25 \mu \mathrm{m}$ ( 5 specimens).

Remarks: Differs slightly from $P$. symphonemoides in having a thinner exine, and a marked decrease in mesh diameter near pores. Partridge (1971) suggested that $P$. symphonemoides first appeared in Miocene strata, and that forms recorded from older rocks (Harris, 1965) are specifically distinct. Rare.

\section{Genus CLAVATIPOLLENITES Couper 1958 \\ Clavatipollenites spp. \\ (Plate 2, Figures 13-16)}

Dimensions: Grain length $19-25 \mu \mathrm{m}$; width $14-19 \mu \mathrm{m}$; ( 8 specimens).

Remarks: Monocolpate pollens with a clavate exine have been referred to this genus. Clavae may be discrete, or united to form an imperfect reticulum. The specimen in Plate 2, Figure 16 resembles $G$. ascarinoides McIntyre, from the New Zealand Miocene. Affinities lie probably with the Chloranthaceae, although Liliaceae may be represented in this morphographic group. Rare, about $1 \%$.

\section{Monocotyledoneae \\ Genus MONOSULCITES Cookson ex Couper 1953 \\ Monosulcites waitakiensis McIntyre 1968 \\ (Plate 2, Figure 20)}

Dimensions: Length $24(32) 36 \mu \mathrm{m}$, width $15(20) 23 \mu \mathrm{m}$.

Remarks: The species identifies closely with $M$. waitakiensis, from the New Zealand Miocene (McIntyre, 1968), which reaches maximum abundance in some Australian basins during that epoch (Partridge, 1971). Affinity lies probably with members of the Palmae. Rare, approximately $1 \%$.

\section{Genus GRAMINIDITES Cookson 1947 ex Potonie 1960 \\ Graminidites sp. cf. G. media Cookson 1947 (Plate 2, Figure 19)}

Dimensions: Diameter 12-18 $\mu \mathrm{m}$ ( 5 specimens).

Remarks: The illustrated form resembles $G$. media, described from the Kerguelen Miocene (Cookson, 1947), but is smaller. Its origin lies almost certainly with Gramineae.

\section{Gymnospermae \\ Genus PODOCAR PIDITES Cookson ex Couper 1953 \\ Podocarpidites sp. \\ (Plate 2, Figures 17, 18)}

Dimensions: Overall length $31-44 \mu \mathrm{m}$ : corpus; length $25-33 \mu \mathrm{m}$, breadth $24-30 \mu \mathrm{m}$ : saccus; length $15-18 \mu \mathrm{m}$, breadth $12-28 \mu \mathrm{m}$.

Remarks: Cannot be identified with any previously described Australian or New Zealand form, but is probably of podocarpaceous origin. Common, around 3\% in Core 29, more abundant in Core 28. 
Pteridophyta

Genus POLYPODIACEOISPORITES Potonié 1956

Polypodiaceoisporites sp. cf. P. retirugatus

Muller in Hekel 1972

(Plate 2, Figures 21, 22)

Dimensions: Equatorial diameter 23(31)38 $\mu \mathrm{m}$.

Remarks: The species is close to that figured by Hekel (1972) from Queensland early Tertiary. It may be distinct in showing an apical narrowing of the cingulum. Affinities lie possibly with the genus Pteris. Common, approximately $6 \%$ of assemblage.

\section{Genus VERRUCATOSPORITES Thomson and Pflug 1953}

\section{Verrucatosporites sp. cf. V. speciosus Harris 1965}

(Plate 2, Figure 24) $\mu \mathrm{m}$.

Dimensions: Length $38(46) 54 \mu \mathrm{m}$, depth $26(31) 38 \mu \mathrm{m}$, width $30-36$

Remarks: Differs slightly from $V$. speciosus Harris in possessing denser, slightly smaller verrucae. Similar types occur in a number of polypodiaceous fern genera, e.g., Cryptogramma, Davallia. Common, approximately $6 \%$ of assemblage.

\section{Genus PEROMONOLITES (Erdtman) ex Couper 1953}

\section{Peromonolites sp.}

(Plate 2, Figure 23)

Dimensions: Length $34(38) 41 \mu \mathrm{m}$, width $24(26) 29 \mu \mathrm{m}$.

Remarks: May be conspecific with $P$. vellosus (Partridge, 1971) in being cavate, and possessing a dense "perispore." $P$. vellosus is known from Paleocene to late Miocene strata in the Gippsland Basin. Rare, around $1 \%$ of assemblage.

\section{Fungi}

Germlings of microthyriaceous fungi (Plate 2, Figures 25-27)

Remarks: From Eocene leaf deposits in Tennessee, Dilcher (1965) described and illustrated growth stages in fossil fungi referable to the family Microthyriaceae. Similar growth stages of ascostromata are common in the cores from Site 254, ranging from the youngest germlings, with shallow invaginations, and frequently showing a darkmargined hyaline central spot, to forms with both radial and tangential walls (Plate 2, Figures 26, 27). The known stratigraphic range for such remains is early Eocene to the present.

Other fungal remains present include masses of hyphae, both septate and nonseptate, and a diversity of spore types, referable to several form genera, including Dicellaesporites Elsik, Fusiformisporites (Rouse), and Pluricellaesporites van der Hammen.

\section{REFERENCES}

Baksi, S. K., 1962. Palynological investigation of Simsang River Tertiaries, South Shillong Front, Assam: Geol. Min. Met. Soc. India Bull., v. 26, p. 1-21.

Baksi, S. K. and Venkatachala, B. S., 1970. Meyeripollis, a new genus from the Tertiary sediments of Assam: J. Geol. Soc. India, v. 11, p. 81-83.

Banerjee, D., 1966. A note on Tertiary microflora from Andaman Islands, India: Pollen Spores, v. 8, p. 203-212.

Cookson, I. C., 1947. Plant microfossils from the lignites of Kerguelen Archipelago: British-Australian-New Zealand Antarctic Research Exped., 1929-31: Reports, Ser. A, v. 2, p. $129-142$.

Cookson, I. C. and Pike, K., 1954. Some dicotyledonous pollen types from Cainozoic deposits in the Australian region: Australian J. Bot., v. 2, p. 197-219.

Dilcher, D., 1965. Epiphyllous fungi from Eocene deposits in western Tennessee, U.S.A.: Palaeontographica B, v. 116, p. $1-54$.

Germeraad, J. H., Hopping, C. A., and Muller, J., 1968. Palynology of Tertiary sediments from tropical areas: Rev. Palaeobot. Palynol., v. 6, p. 189-348.

Good, R., 1964. The geography of the flowering plants. (3rd ed.): London (Longmans, Green \& Co.).

Harris, W. K., 1965. Basal Tertiary microfloras from the Princetown area, Victoria, Australia: Palaeontographica B, v. 115 , p. $75-106$.

Hekel, H., 1972. Pollen and spore assemblages from Queensland Tertiary sediments: Geol. Surv. Queensland, Pal. Papers, v. 30, p. 1-34.

Heusser, C. J., 1971. Pollen and spores of Chile: Tucson (University of Arizona Press).

Martin, H. A., 1972. The palynology of some Tertiary Pleistocene deposits, Lachlan River Valley, New South Wales: Australian J. Bot., Suppl. Ser. 6, p. 1-57.

McIntyre, D. J., 1968. Further new pollen species from New Zealand Tertiary and uppermost Cretaceous deposits: New Zealand J. Bot., v. 6, p. 177-204.

Muller, J., 1968. Palynology of the Pedawan and Plateau Sandstone Formations (Cretaceous-Eocene) in Sarawak, Malaysia: Micropaleontology, v. 14, p. 1-37.

Partridge, A. D., 1971. Stratigraphic palynology of the onshore Tertiary sediments of the Gippsland Basin, Victoria: Unpublished M.S. Thesis, University of New South Wales.

Ramanujam, C. G. K., 1966. Palynology of the Miocene lignite from South Arcot district, Madras, India: Pollen Spores, v. 7, p. 149-203.

Straka, H., Simon, A., and Cerceau-Larrival, M. T., 1967. Palynologia Madagassica et Mascarenica. Fam. 155-166: Pollen Spores, v. 9, p. 427-466. 



\section{PLATE 1}

All specimens from Sample 29-1, 124-128 cm;

magnification $\times 1000$.

Figures 1-5 Tricolpites sp. cf. T. reticulatus Cookson.

$1-4$. Grains in polar view.

5. Grain in equatorial view.

Figures 6-8 Tricolpites $\mathrm{sp}$.

Figures 9-13 Striatricolporites $\mathrm{sp}$.

9-11. Grains in polar view.

12, 13. Grains in equatorial view.

Figures 14, 15 Tricolpites sp. cf. T. asperamarginatus McIntyre.

Figures 16-18 Rhoipites sp. 1.

Figures 19, 20 cf. Echitricolporites sp.

Figures 21, 22, Rhoipites sp. 2.

$27-30$

Figures 23-26 cf. Malvacipollis $\mathrm{sp}$. 
PLATE 1
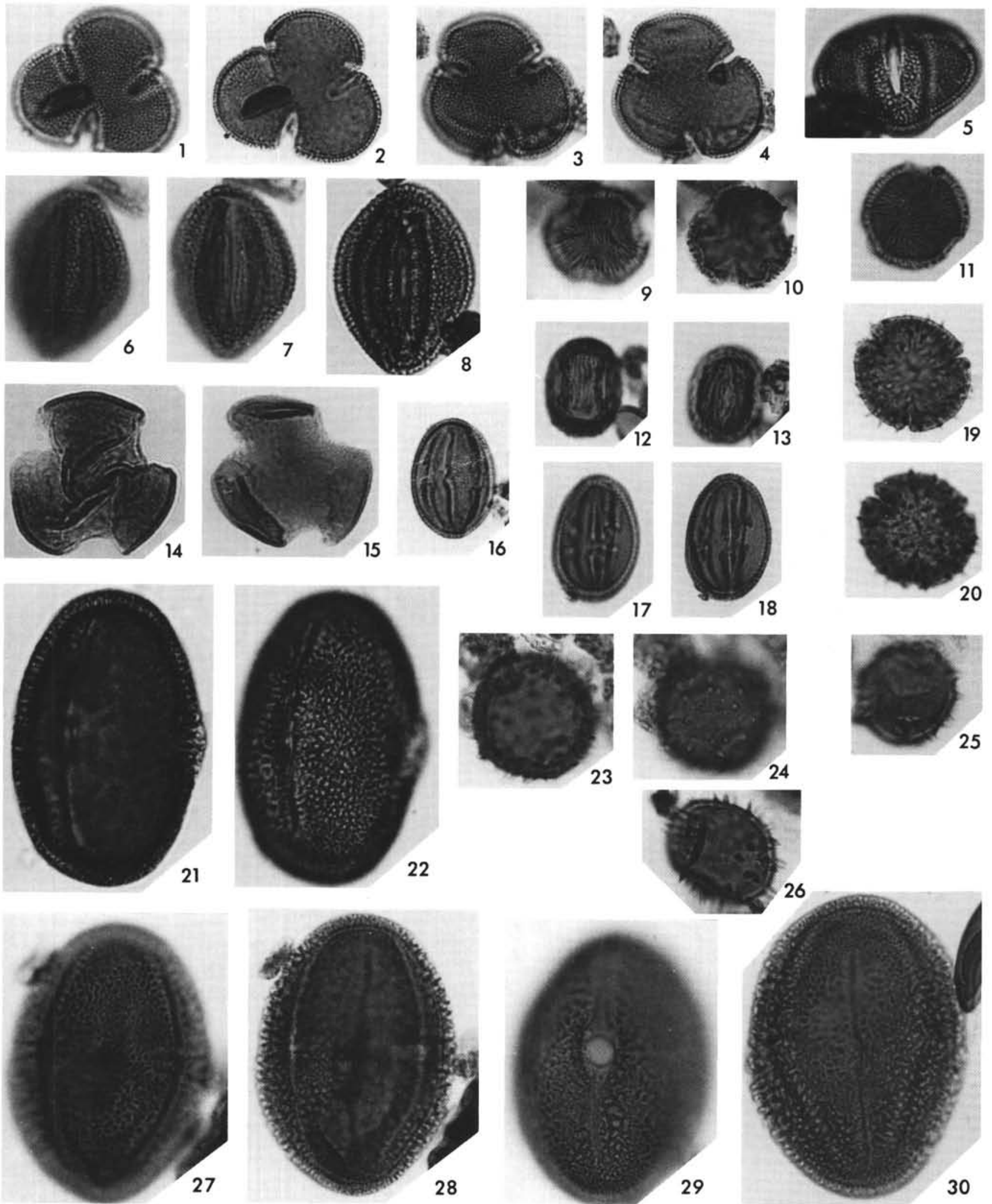
PLATE 2

All specimens from Sample 29-1, 124-128 cm; magnification $\times 1000$.

Figure 1 Cupanieidites orthoteichus Cookson and Pike.

Figures 2-4 Myrtaceidites sp. cf. M. mesonesus Cookson and Pike.

Figures 5,6 Proteacidites $\mathrm{sp}$. cf. P. symphonemoides Cookson.

Figures 7-12 Meyeripollis sp.

Figures 13-16 Clavatipollenites spp.

Figures 17, 18 Podocarpidites sp.

17. Proximal focus.

18. Distal focus.

Figure 19 Graminidites sp. cf. G. media Cookson.

Figure $20 \quad$ Monosulcites waitakiensis McIntyre.

Figures 21, 22 Polypodiaceoisporites $\mathrm{sp}$. cf. P. retirugatus Muller. 21. Proximal focus.

22. Distal focus.

Figure $23 \quad$ Peromonolites sp.

Figure $24 \quad$ Verrucatosporites sp. cf. V. speciosus Harris.

Figures 25-27 Germlings of microthyriaceous fungi. 


\section{PLATE 2}
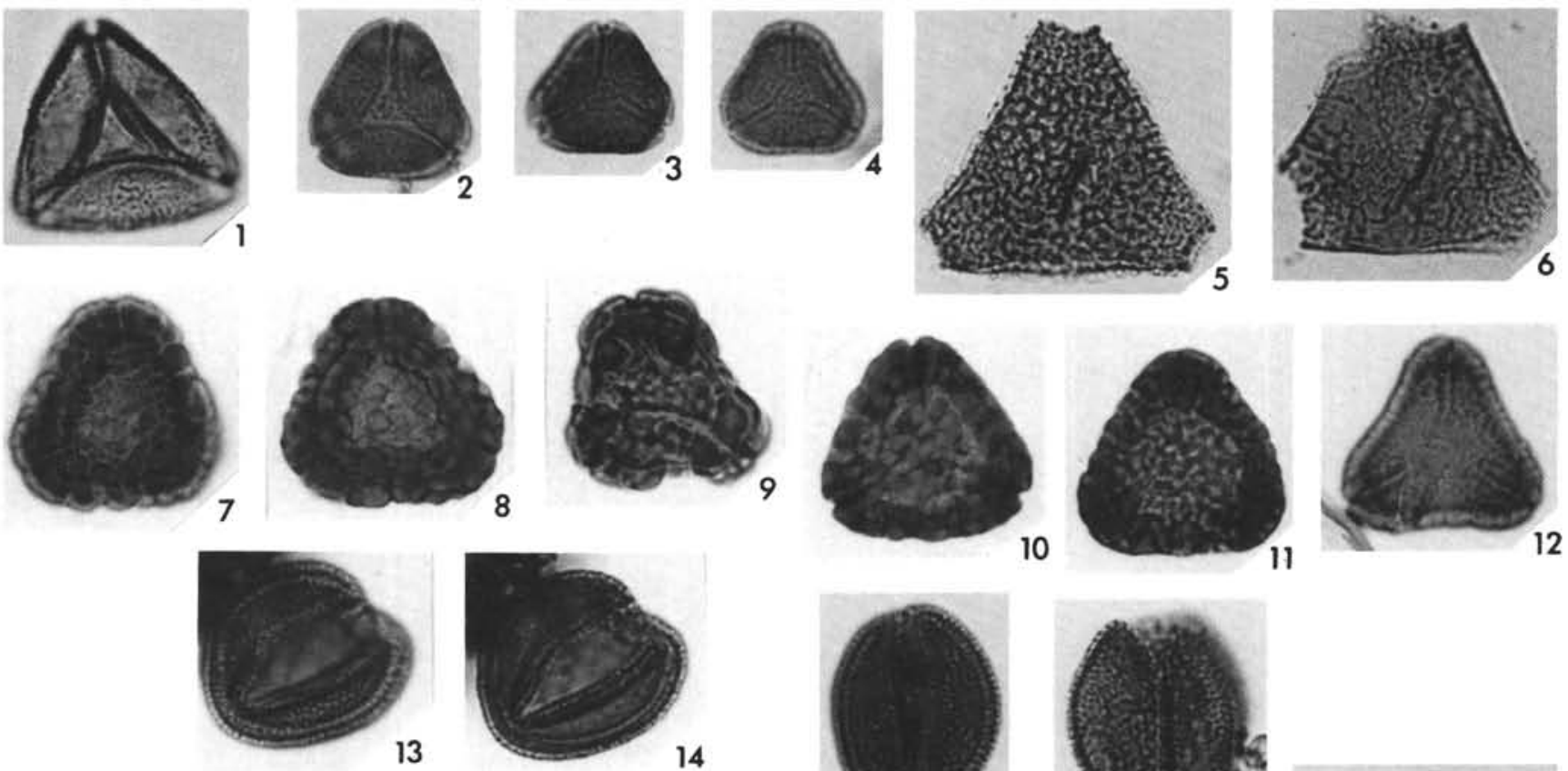

13

14
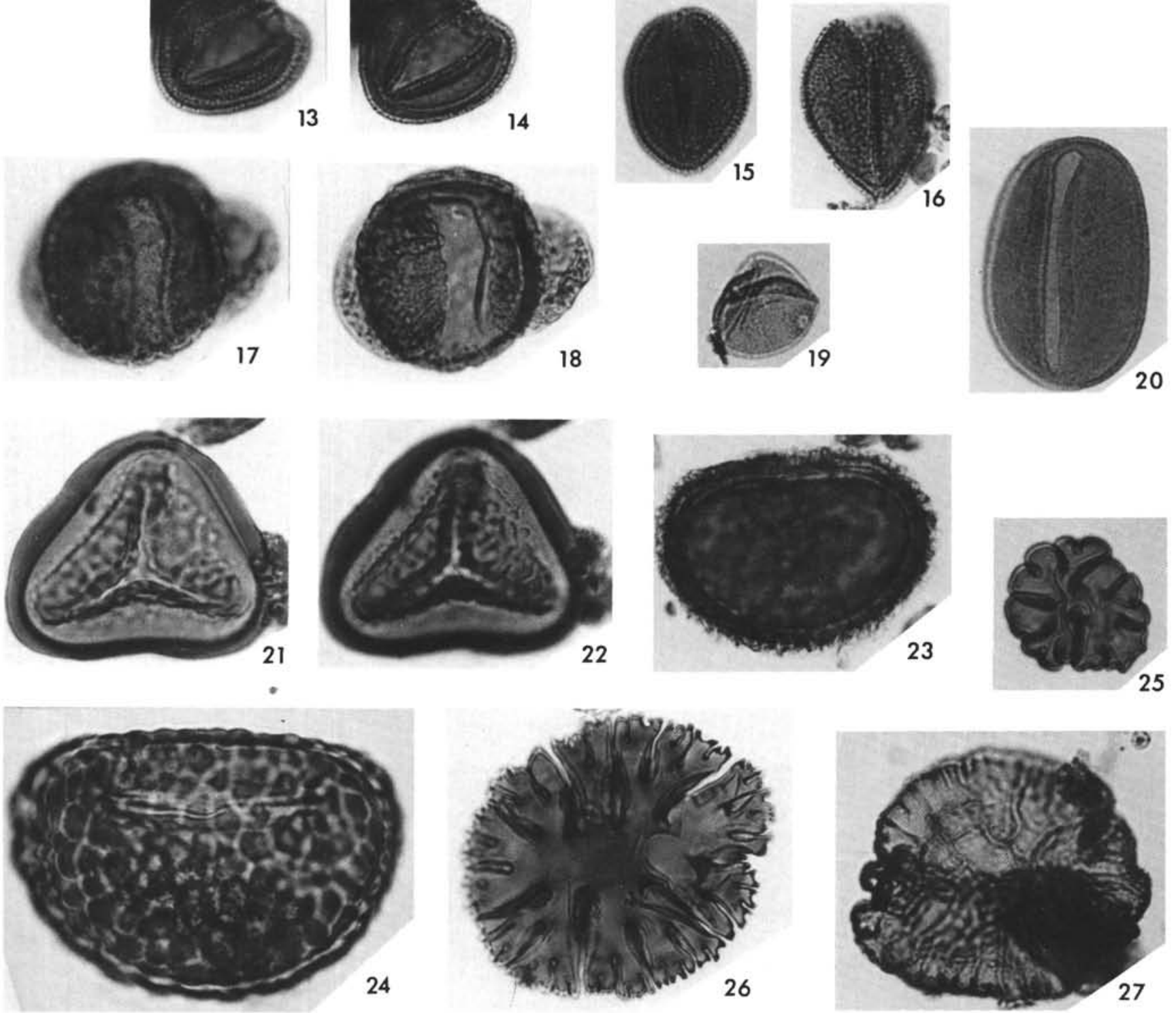